\title{
Incorporating Islamic Value in Corporate Social Responsibility (CSR) Practice of Malaysia Small Medium Enterprises (SMEs) Food Operators: Does Manager's Religiosity Influence CSR Practice?
}

Mohd Aidil Riduan Awang Kader, Suhana Mohezar, Mohammad Nazri, Nor Khairunnisa Mat Yunus and Roslina Ali

To Link this Article: http://dx.doi.org/10.6007/IJARBSS/v11-i11/10868

DOI:10.6007/IJARBSS/v11-i11/10868

Received: 03 September 2021, Revised: 25 September 2021, Accepted: 20 October 2021

Published Online: 04 November 2021

In-Text Citation: (Kader et al., 2021)

To Cite this Article: Kader, M. A. R. A., Mohezar, S., Nazri, M., Yunus, N. K. M., \& Ali, R. (2021). Incorporating Islamic Value in Corporate Social Responsibility (CSR) Practice of Malaysia Small Medium Enterprises (SMEs) Food Operators: Does Manager's Religiosity Influence CSR Practice? International Journal of Academic Research in Business and Social Sciences, 11(11), 105 - 115.

\section{Copyright: (c) 2021 The Author(s)}

Published by Human Resource Management Academic Research Society (www.hrmars.com)

This article is published under the Creative Commons Attribution (CC BY 4.0) license. Anyone may reproduce, distribute, translate and create derivative works of this article (for both commercial and non-commercial purposes), subject to full attribution to the original publication and authors. The full terms of this license may be seen at: http://creativecommons.org/licences/by/4.0/legalcode

Vol. 11, No. 11, 2021, Pg. $105-115$

Full Terms \& Conditions of access and use can be found at http://hrmars.com/index.php/pages/detail/publication-ethics 


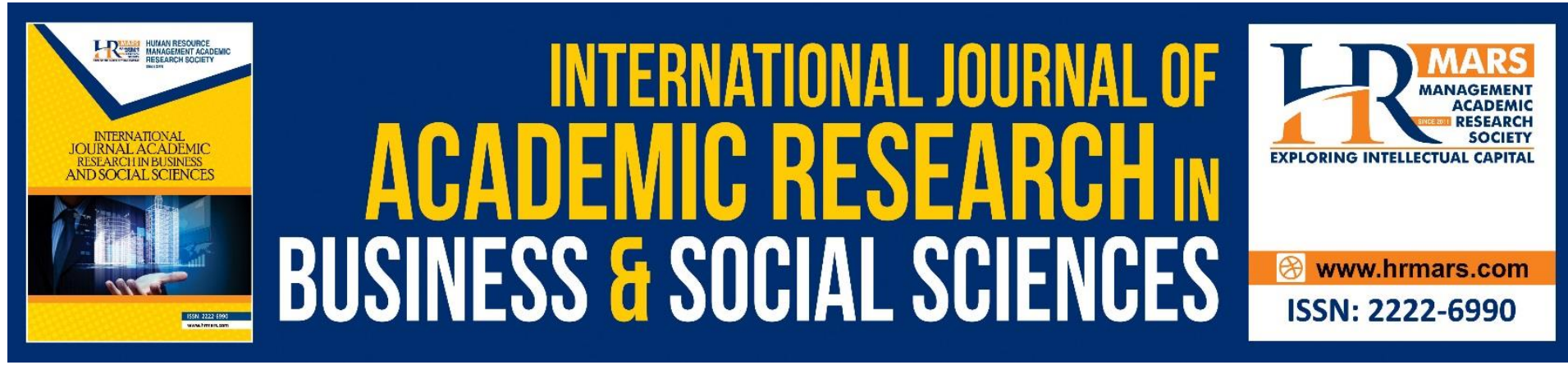

\title{
Incorporating Islamic Value in Corporate Social Responsibility (CSR) Practice of Malaysia Small Medium Enterprises (SMEs) Food Operators: Does Manager's Religiosity Influence CSR Practice?
}

Mohd Aidil Riduan Awang Kader ${ }^{1}$, Suhana Mohezar ${ }^{2}$, Mohammad Nazri², Nor Khairunnisa Mat Yunus ${ }^{3}$ and Roslina $\mathrm{Ali}^{3}$

${ }^{1}$ Faculty of Business and Management, Universiti Teknologi MARA Pahang, Jengka Campus, 26400 Bandar Pusat Jengka, Pahang, Malaysia, ${ }^{2}$ Faculty of Business and Accountancy, University Malaya 50603 Kuala Lumpur, Malaysia, ${ }^{3}$ Faculty of Business and Management, Universiti Teknologi MARA Pahang, Raub Campus, 27600 Raub, Pahang, Malaysia Email: aidilriduan@pahang.uitm.edu.my

\begin{abstract}
While corporate social responsibility (CSR) practice has long received considerable attention in the food and agricultural research arena, empirical studies on CSR practice of food companies involving small and medium enterprises (SME) are still scarce. Given the importance of CSR implementation among SMEs, there is a need for a study to show how CSR affects the corporate reputation of the companies. Therefore, this study aims to investigate the extent to which CSR practices are influenced by the level of organizational policy and managers' religiosity among local SMEs food operators and its impact on corporate reputation. This study employed a survey method, and the sampling frame for this study was drawn from the list of food manufacturers registered with the Small and Medium Industries Development Corporation (SMIDEC) in Malaysia. A total of 264 questionnaires were analyzed by using PLS-SEM. This study found that organizational policy and managers' religiosity had significant relationship with CSR practice. This research has important implications to regulators, listed firms, consumers, and capital market participants. Although it is much more complex to identify, investigate and communicate CSR in the small business, this area deserves more attention due to its potential impact on the global economy.
\end{abstract}

Keywords: Corporate Social Responsibility (CSR), Food Supply Chain, Islamic Value, Managers' Religiosity, Small Medium Enterprise 


\section{Introduction}

Corporate Social Responsibility (CSR) is an added value to the corporate reputation of an organization. Embedded in CSR policy is standard behavioral rules that require the respective organization to adopt productive and positive manners in its activities due to its significance towards the advancement of the society. In other words, this good practice has a positive impact on customers, who consume the organizations' products or services. Therefore, to remain competitive, organizations must not only focus on their products and services, but they also need to show their concern towards society. The undertaking of CSR as part of a firm's business strategy applies not only to big organizations but also small and medium organizations. In Malaysia, the role of the latter or enterprises cannot be denied as they constitute about $99 \%$ of total business establishments in Malaysia. In terms of employment, those enterprises employ more than 7.3 million workers in 2019 (Department of Statistics Malaysia, 2020). In fact, in 2019 alone, SMEs contribute 38.9\% of Gross Domestic Product (GDP).

Although the CSR practice has reasonably proven to have an impact on corporate reputation (Diogo \& Neal 2017), not many organizations, particularly SMEs' business owners, have sufficient financial capabilities to enhance their degree of CSR practice. Moreover, this weakness is complicated in certain industries as some organizations have more direct contact with customers. As a result, their CSR practices are more prone to customers' scrutiny. This phenomenon has awakened the organization that there are other factors that can contribute to CSR practice, especially in food organizations. Subsequent to that, this study is driven to analyze how organizational policy and managers' religiosity can have an effect on CSR practice, particularly in businesses involving food operators, and the degree to which this has impact on the organization's corporate reputation. In an attempt to seek answers on the above two, this study proposes the following research questions: 1) What is the relationship between CSR practice and corporate reputation? 2) What are the effects of organizational policy and managers' religiosity on CSR practice? The results of this study are expected to provide better understanding on the potentiality of these two factors in influencing CSR practice to varying degrees, and the direct impact of this result on corporate reputation, in the context of SMEs' business environment in Malaysia.

\section{Literature Review \\ Corporate Reputation}

Corporate reputation could be referred as a reflection of the degree to which the public is satisfied that firms are meeting their expectations with products and services (Brammer \& Pavelin, 2016) and enhance the firm's performance (Bahta et al., 2021; Chef et al., 2021; Pallathadka \& Pallathadka, 2020). New and emerging issues in the market have called upon firms to focus on building their reputation in order to enhance their credibility and image. For example, Diogo and Neal (2017) investigated the relationship between CSR strategies and company goodwill and reputation in UK food retailers. The study found that CSR strategies are very important for a company to improve corporate reputation. Gagalyuk (2017) had performed a research on the impact of CSR transparency of agro companies in Ukraine. The result revealed that CSR transparency can be used to gain competitive advantage and increase corporate reputation especially in the long run. Drawing upon these literatures, this study postulates that:

H1: CSR practice in food supply chain is positively related to a firm's corporate reputation. 


\section{Organizational Policy}

Firms that incorporate ethical responsibility in their organizational policy may encompass activities and business processes that are not necessarily codified into law, yet are expected of business by societal member. Firms have the obligation to pursue these policies, to make those decisions, or to follow those lines of action that are desirable in terms of the objectives and give values to the stakeholders (Minette \& Kiosani, 2021) and society (Maisam, 2017). The identifying process of a common set of standard policy that fit each firm in supply chain is difficult because corporate characteristics such as organizational culture, managerial policies and operational routines influence the importance of measures (Callado \& Jack, 2017). Having organisations' commitment and supportive culture may enhance the strategic importance of the CSR practice (Perry, 2012). Moreover, since the incorporation of CSR into firm operations entails extensive resources, securing the interests of top management commitment on funding is imperative for successful accomplishment. A study by Zou et al. (2021) found that a lack of top management commitment will lead to the unsuccessful of SMEs in Pakistan to involve in CSR activities. Based on this argument, the following hypothesis is proposed:

H2: Organizational policy is positively related to CSR practice in the food supply chain.

\section{Managers' Religiosity}

CSR exercise may also be driven by various personal values and interests of individual managers, guided by their religiosity (Iguchi et al., 2021; Mazereeuw et al., 2014). Previous studies had shown that managers' religiosity plays an important role as contributing factor towards SMEs' performance such as in Saudi Arabia (Alharbi et al., 2021) and Indonesia (Desiyanti \& Kassim, 2020). Moreover, Ghadas et al (2018) revealed that it is crucial for managers to include the religiosity aspect in their business in terms of CSR so that it can give the highest benefit to the society and increase organizational performance and reputation. Tahir et al (2015) investigated the managers' perception towards religiosity and CSR in the Malaysian context. They revealed that managers perceived religiosity and CSR practices are an important part of business. Most religions instil responsible values which may enable managers to perceive the consequences of ethical/unethical environmental practice towards consumers. An Islamic market is characterized by norms that concern both parties -buyers and sellers. Business contracts and commercial transactions that do not incorporate certain ethical discipline and elements would be considered as lack of perfection in the light of the code of manners and decency (Jamali \& Sdiani, 2013). Guided by this principle, a person's daily communications and transactions as well as business activities and operations are therefore would be inspired by the values of truthfulness, tolerance, firmness and fairness. Based on these literatures, we propose that:

H3: Managers' religiosity is positively related to CSR practice in the food supply chain.

Following the extant literature, a research model was developed. The model posits that CSR practice has a positive influence on a firm's corporate reputation. In addition, CSR practice is expected to be affected by the organizational policy and managers' religiosity (Figure 1). 


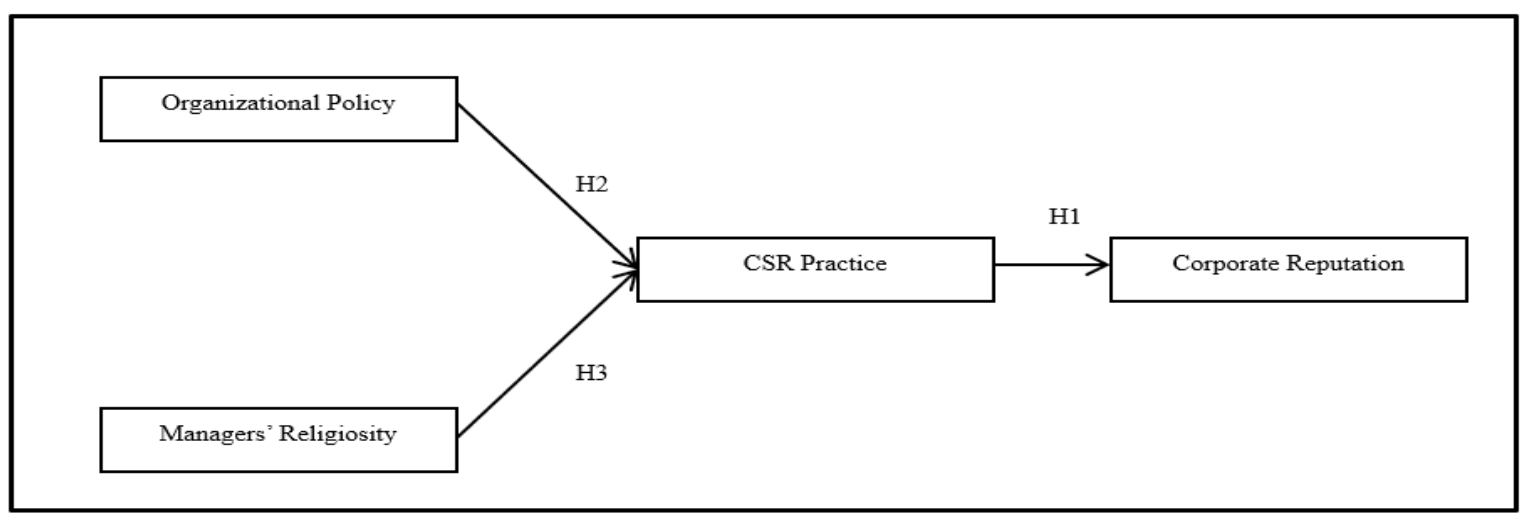

Figure 1 Research Model

\section{Methodology}

The target population of this study is food manufacturers including CEO, managers and owners who are responsible in rising business practices. The process of data collection was carried out through survey method, by using mail questionnaires to test on the research model and hypotheses developed. This questionnaire was validated through a pilot test. Twenty-seven SMEs operators were randomly selected from a database to perform the pilot study. Based on the responses from participants in the pre-test, minor modifications were made to the questionnaire for the next phase of data collection for larger study. The sampling questionnaire structures for this study were obtained from the list of The Small and Medium Industries Development Corporation (SMIDEC) in Malaysia. A total number of 1200 of questionnaires were posted to respondents. In total, 264 valid questionnaires were obtained to be process and analysed, yielding a response rate of 22 percent.

\section{Results and Discussion}

This study conducted convergent and discriminant validity tests to ensure that the measurements are in agreement and do not reflect other variables (Hair et al., 2013). Convergent validity was examined based on factor loadings, composite reliability and average variance extracted (AVE). As indicated in Table 1, all the variables had composite reliability and AVE greater that the cut-off point of 0.7 and 0.5 respectively (Hair et al., 2013). Three items measuring the CSR practice were dropped due to the low factor loadings (Bagozzi \& Yi, 1988). These results demonstrate the convergent validity of the measures used. In this study, discriminant validity was tested based on Fornell and Larcker (1981) approach. All of the scales appear to have a substantially higher AVE value compared to their correlation with other constructs, providing evidence of discriminant validity (Table 2). The results of the measurement model indicate that various validity and reliability criteria are satisfied. Therefore, constructs developed in this measurement model could be used to test the structural model and the associated hypotheses. 
Table 1 Convergent Validity

\begin{tabular}{|c|c|c|c|c|c|}
\hline Variables & Items & $\begin{array}{l}\text { Factor } \\
\text { Loading }\end{array}$ & T-value & $\begin{array}{l}\text { Average } \\
\text { Variance } \\
\text { Extracted }\end{array}$ & $\begin{array}{l}\text { Composite } \\
\text { Reliability }\end{array}$ \\
\hline \multirow{4}{*}{$\begin{array}{l}\text { Corporate } \\
\text { reputation }\end{array}$} & CR1 & $0.796 * * *$ & 16.863 & \multirow[t]{4}{*}{0.563} & \multirow[t]{4}{*}{0.839} \\
\hline & CR2 & $0.766 * * *$ & 17.377 & & \\
\hline & CR3 & $0.719 * * *$ & 12.783 & & \\
\hline & CR4 & $0.71 * * *$ & 13.266 & & \\
\hline Organizational & OP1 & $0.792 * * *$ & 16.258 & \multirow[t]{3}{*}{0.656} & \multirow[t]{3}{*}{0.851} \\
\hline \multirow[t]{2}{*}{ Policy } & OP2 & $0.793 * * *$ & 16.123 & & \\
\hline & OP3 & $0.836 * * *$ & 22.918 & & \\
\hline \multirow{5}{*}{$\begin{array}{l}\text { Managers' } \\
\text { religiosity }\end{array}$} & MR1 & $0.749 * * *$ & 19.034 & \multirow[t]{5}{*}{0.566} & \multirow[t]{5}{*}{0.867} \\
\hline & MR2 & $0.702 * * *$ & 14.401 & & \\
\hline & MR3 & $0.826 * * *$ & 31.205 & & \\
\hline & MR4 & $0.754 * * *$ & 18.065 & & \\
\hline & MR5 & $0.712^{* * *}$ & 15.538 & & \\
\hline Corporate Social & $\mathrm{CS} 2$ & $0.639 * * *$ & 13.97 & \multirow[t]{7}{*}{0.513} & \multirow[t]{7}{*}{0.838} \\
\hline \multirow[t]{6}{*}{ Responsibility } & CS4 & $0.695 * * *$ & 19.436 & & \\
\hline & CS6 & $0.745^{* * *}$ & 23.961 & & \\
\hline & CS7 & $0.755 * * *$ & 28.112 & & \\
\hline & $\mathrm{CS} 8$ & $0.736 * * *$ & 22.434 & & \\
\hline & $\operatorname{CS9}$ & $0.734 * * *$ & 21.917 & & \\
\hline & CS10 & $0.696 * * *$ & 19.752 & & \\
\hline
\end{tabular}

Note: CS1, CS3 and CS5 were dropped due to the low factor loading, $* * * p<0.001$

Table 2 Discriminant Validity

\begin{tabular}{|c|c|c|c|c|c|c|}
\hline & Mean & SD & CS & CR & MR & OP \\
\hline \multirow[t]{2}{*}{ Corporate Social Responsibility (CS) } & 3.44 & 0.8 & 0.6 & & & \\
\hline & & 8 & 3 & & & \\
\hline \multirow[t]{2}{*}{ Corporate reputation (CR) } & 4.71 & 0.8 & 0.3 & 0.7 & & \\
\hline & & 9 & 9 & 5 & & \\
\hline \multirow[t]{2}{*}{ Managers' religiosity (MR) } & 3.55 & 0.2 & 0.3 & 0.3 & 0.7 & \\
\hline & & 1 & 5 & 2 & 5 & \\
\hline \multirow[t]{2}{*}{ Organizational Policy (OP) } & 3.75 & 0.6 & 0.2 & 0.6 & 0.2 & 0.8 \\
\hline & & 6 & 9 & 2 & 5 & 1 \\
\hline
\end{tabular}

By assuming that the measurement model satisfied the psychometric assessment, a structural model was constructed based on the results of the measurement model. Nonparametric bootstrapping was applied (Wetzels et al., 2009) with 2000 replications to test the structural model. The predictive accuracy of the model was evaluated in terms of the portion of variance explained. The results suggest that the model is capable of explaining $26 \%$ of the variance in 
corporate reputation and $40 \%$ of the variance in corporate social responsibility. As suggested by Chin et al (2003), a hierarchical approach was employed to test the hypotheses, in which a model was estimated with the main effects (and covariates) only and then added the interaction effects. The results indicate that the effects of organizational policy $(\beta=0.226, p$ $<0.01)$, and managers' religiosity $((\beta=0.311, p<0.01)$ on corporate social responsibility are significant and positive (Table 3 ). As such, $\mathrm{H} 2$ and $\mathrm{H} 3$ are supported. This study also found that corporate social responsibility is significantly related to corporate reputation $(\beta=0.371$, $\mathrm{p}<0.01$ ), supporting $\mathrm{H} 1$.

Table 3 Structural Model Analysis

\begin{tabular}{|c|c|c|c|c|}
\hline Hypotheses & Relationship & $\begin{array}{l}\text { Path } \\
\text { Coefficien } \\
\mathbf{t}\end{array}$ & T-value & Decision \\
\hline $\mathrm{H}_{1}$ & $\begin{array}{l}\text { Corporate social responsibility }-> \\
\text { corporate reputation }\end{array}$ & $0.371^{* *}$ & 6.292 & $\begin{array}{l}\text { Supporte } \\
\text { d }\end{array}$ \\
\hline $\mathrm{H}_{2}$ & $\begin{array}{l}\text { Organizational policy -> corporate } \\
\text { social responsibility }\end{array}$ & $0.226 * *$ & 4.029 & $\begin{array}{l}\text { Supporte } \\
\text { d }\end{array}$ \\
\hline $\mathrm{H}_{3}$ & $\begin{array}{l}\text { Managers' religiosity -> corporate } \\
\text { social responsibility }\end{array}$ & $0.311 * *$ & 7.051 & $\begin{array}{l}\text { Supporte } \\
\text { d }\end{array}$ \\
\hline
\end{tabular}

The study intends to investigate the impact of corporate reputation and Islamic values. It is found that both organizational policy and managers' religiosity influence organizations to accept good CSR practice. This study also revealed that organizational policy has significant relationship with CSR practice. This finding is congruent with the study by Minette and Kiosani (2021), which found that firms that incorporate ethical responsibility in their organizational policy may encompass activities and business processes that are not necessarily codified into law, yet are expected of business by societal member. In addition, a study by Perry (2012) also proved that by having organisations' commitment and supportive culture enhanced the strategic importance of the CSR practice. Moreover, since the incorporation of CSR into firm operations entails extensive resources, securing the interests of top management commitment on funding is imperative for successful accomplishment. Having top management commitment and supportive culture may enhance the strategic importance of the CSR practice (Callado \& Jack, 2017; Carter \& Jennings, 2004).

The finding from this study also has proved that managers' religiosity has relationship with CSR practice. Religious orientation has a strong influence on business success (Alharbi et al., 2021; Desiyanti \& Kassim, 2020). Firms that incorporate the Islamic ethical values such as truthfulness, tolerance, firmness and fairness are more encouraged to sacrifice, give up and spend their wealth on the needy society and community, while expected reward only from Allah. The responsibility and spirits of sacrifice which nurture by Islam help in removing selfcenteredness and promotes compassion, caring, cooperation and harmony among people (Dusuki, 2008). The finding of this study is also congruent with several studies (Iguchi et al., 2021; Mazereeuw et al., 2014; Tahir et al., 2015) who revealed that managers perceived religiosity and CSR practices are an important part of business.

Some studies have demonstrated that CSR practice lead to a firm's corporate reputation (Bahta et al., 2021; Chef et al., 2021; Diogo \& Neil, 2017; Gagalyuk, 2017). The finding suggests 
that the responding firms realise the benefits of CSR practice in enhancing their corporate image. The results obtained showed the buyers' perceptions towards suppliers CSR activities may encourage buyers' good responsiveness in supporting suppliers' products. Today, most companies started to demonstrate their commitment to various cau ses are perceived as more philanthropic than companies which corporate social responsibility endeavour are non-exist. The impact on the buyers that have awareness on the CSR existence in the business is vital. It may foster buyers' confidence that the firms have concern on the quality standards, enhance the corporate reputation and cares about the community and environmental welfares. Previous studies also confirmed that CSR practice is important as a sustainable strategy to growth and compete longer in the business (Desiyanti \& Kassim, 2020; Ghadas et al., 2018; Samuel et al., 2011).

While few studies (Sardianou et al., 2017; Pomering, 2017) suggest that firms may not able to reap the potentials of CSR if their customers are not fully aware of the CSR characteristics embedded in the products offered, this research however provides conflicting result. This could happen due to the buyers' emotional behaviour during the study. They are more attracted to moral commitment rather than promoting CSR by marketing the products (Öberseder et al., 2011). Culture of Malaysian which is known as collectivisms culture, is one that is based on valuing the needs of a group or a community over the individual which burden a relevant role in influencing an individual behaviour (Hofstede \& Bond, 1988). The way a person looks at a new products or business must obtain stronger feedback and support from others in order to disseminate the feedback to their relatives and friends (Komodromos \& Melanthiou, 2014). Their positive experience and feedback on the CSR activities in the social networking may enhance the company reputation overall.

\section{Conclusion}

This study has achieved its purpose to fulfil the primary objective on determining the relationship between CSR practice and corporate reputation. In addition, it has also examined the effects of organizational policy and managers' religiosity on CSR practice, as the second objective. The results provide empirical evidence with regards to the validity and reliability of the proposed model about corporate reputation of small and medium sized food organizations. This model has confirmed previous empirical studies that claim organizational policy and managers' religiosity are linked with CSR practice. The results also demonstrate that out of the two factors, managers' religiosity appears to be the most important predictor of CSR practice among small and medium enterprises that involved with food businesses in Malaysia. The findings have practical implications for SME business owners and regulatory bodies, for example, the SME Corp, in developing a policy that can help to improve SME business performance by means of corporate reputation. Furthermore, by involving in responsive activities, the respective organizations can help contribute to the economy and community. Eventually, this brings about positive impact on the SMEs' corporate reputation.

As a conclusion, this study has filled the gap in the scarce literature about corporate reputation and CSR practice of food operators within small and medium enterprises (SMEs). It also suggests that when positioning the right kind of image and getting more profits, SME companies have to take into account of the wellbeing of society. Additionally, to be on the right track, the business owners should also ensure that they have in place the right kind of policy that reinforces their managers' religiosity values. A more in-depth study can be 
conducted in the future by way of case studies as it can possibly provide richer insights to other factors that contribute to CSR practice among SMEs in Malaysia. Moving forward, the current framework needs to be tested by applying it to different categories of SMEs in order to have a clearer picture of its impact on various sectors of the economy.

Many previous studies regarding managers' religiosity on CSR practices have been conducted in various fields and organizations. However, there is a lack of study that focuses on how organizational policy and managers' religiosity can influence CSR practice, particularly in SMEs involving food operators, and the degree to which this has an impact on the organization's corporate reputation. As a result, this study may be able to contribute to existing knowledge by enhancing and adding a new dimension to the literature on the factors that influence CSR to practice in the setting of Malaysian SMEs. Because it involves a manager's religious convictions in conducting business, religiosity appears to be one of the most crucial criteria in deciding CSR activity. Moreover, financial constraints are one of the problems for SMEs. Hence, CSR practice can help a company's reputation indirectly. This is important in the context of SMEs since CSR can take many forms, including monetary and non-monetary activities such as charity work and food donations to the homeless and those in need. Furthermore, CSR should be included in organizational policy, particularly for SMEs, because it is one of the strategies to strengthen stakeholders' confidence in SMEs' capabilities and reputation. Many consumers are affected economically and financial instability as a result of the Covid-19 pandemic. So, by including CSR as one of the policies in their business, SMEs can enhance their corporate reputation through CSR activities. Therefore, SMEs food operators need to consider these two factors in CSR practices in conducting business because it can attract more customers and retain existing customers due to consumer trust in the quality of products offered. This can enhance an SME's corporate reputation and revenues, as well as promote a harmonious business atmosphere and provide more benefit the community.

\section{References}

Alharbi, R. K., Yahya, S. B., \& Kassim, S. (2021). Impact of religiosity and branding on SMEs performance: does financial literacy play a role? Journal of Islamic Marketing, https://doi.org/10.1108/JIMA-08-2019-0162

Bagozzi, R. P., \& Yi, Y. (1988). On the evaluation of structural equation models. Journal of the Academy of Marketing Science, 16(1), 74-94.

Bahta, D., Yun, J., Islam, M. R., \& Bikanyi, K. J. (2021). How does CSR enhance the financial performance of SMEs? The mediating role of firm reputation. Economic ResearchEkonomska Istraživanja, 34(1), 1428-1451.

Brammer, S. J., \& Pavelin, S. (2016.) Corporate Reputation and Corporate Social Responsibility. In: Guler A, Crowther D, A Handbook of Corporate Governance and Social Responsibility, pp 437-447, USA: Routledge

Callado, A. A. C., \& Jack, L. (2017). Relations between usage patterns of performance indicators and the role of individual firms in fresh fruit agri-food supply chains. Journal of Applied Accounting Research, 18(3), 375-398.

Carter, C. R., \& Jennings, M. M. (2004). The role of purchasing in corporate social responsibility: A structural equation analysis. Journal of Business Logistics, 25(1), 145186.

Chef, W., Abdel-Maksoud, A., \& Farooq, M. O. (2021). CSR initiatives, organizational performance and the mediating role of integrating CSR into management control 
systems: Testing an inclusive model within SMEs in an emerging economy. Journal of Management Control, https://doi.org/10.1007/s00187-021-00323-6

Chin, W. W., Marcolin, B. L., \& Newsted, P. R. (2003). A partial least squares latent variable modeling approach for measuring interaction effects: Results from a Monte Carlo simulation study and an electronic-mail emotion/adoption study. Information systems research, 14(2), 189-217.

Department of Statistics Malaysia. (2020). Small and Medium Enterprises Performance 2019. https://www.dosm.gov.my/v1/index.php?r=column/cthemeByCat\&cat=159\&bul_id= VjM1enZ2RmIVRDVTNFAwRWZiZUs3QT09\&menu_id=TE5CRUZCblh4ZTZMODZIbmk2 aWRRQT09\#: :text=SMEs\%20employment\%20comprised\%20of\%2048.4,persons)\%2 0(Chart\%203

Desiyanti, R., \& Kassim, M. A. A. (2020). Financial Literacy on Business Performance: The Moderating Effect of Religiosity Among SMEs In Sumatera, Indonesia, International Journal of Academic Research in Accounting, Finance and Management Science. 10(2), 87-99.

Diogo, S. M., \& Neal, H. (2017). Comparing UK food retailers corporate social responsibility strategies. British Food Journal, 119(3), 658-675.

Dusuki, A. W. (2008). What Does Islam Say about Corporate Social Responsibility?", Review of Islamic Economics, 12(1), 5-28.

Fornell, C., \& Larcker, D. F. (1981). Evaluating structural equation models with unobservable and measurement error. Journal of Marketing Research, 18(1), 39-50.

Gagalyuk, T. (2017). Strategic role of corporate transparency: the case of Ukrainian agroholdings. International Food and Agribusiness Management Review, 20(2), 257278.

Ghadas, Z. A. A., Aziz, H. A., Udin, N. M., \& Radzi, M. S. N. M. (2018). "Social Corporation" The Sharia Business Entity Model: A Corporate Structure with Embodied CSR. International Journal of Academic Research in Business and Social Sciences, 8(12), 1569-1578.

Hair, J. F., Hult, G. T. M., Ringle, C. M., \& Sarstedt, M. (2013). A Primer on Partial Least Squares Structural Equation Modelling (PLS-SEM). Thousand Oaks: Sage.

Hofstede, G., \& Bond, M. H. (1988). The Confucius connection: from cultural roots to economic growth. Organizational Dynamics, 16, 4-21.

Iguchi, H., Katayama, H., \& Yamanoi, J. (2021). CEOs' religiosity and corporate green initiatives. Small Bus Econ. https://doi.org/10.1007/s11187-020-00427-8

Jamali, D., \& Sdiani, Y. (2013). Does religiosity determine affinities to CSR? Journal of Management, Spirituality \& Religion, 10(4), 309-323.

Komodromos, M., \& Melanthiou, Y. (2014). Corporate Reputation Through Strategic Corporate Social Responsibility: Insights From Service Industry Companies. Journal of Promotion Management, 20(4), 470-480.

Maisam, A. (2017). Towards socially sustainable supply chains - themes and challenges. European Business Review, 29(3), 261-303.

Mazereeuw, D. S. C., Graafland, J., \& Kaptein, M. (2014). Religiosity, CSR attitudes, and CSR behavior: an empirical study of executives' religiosity and CSR. Journal of Business Ethics, 123(3), 437-459.

Minette, E. E., \& Kiosani, T. (2021). CSR and Business Strategies: SMEs. https://www.divaportal.org/smash/get/diva2:1569113/FULLTEXT01.pdf 
Öberseder, M., Schlegelmilch, B. B., \& Gruber, V. (2011). Why don't consumers care about CSR? A qualitative study exploring the role of CSR in consumption decisions. Journal of Business Ethics, 104(4), 449-460.

Pallathadka, H., \& Pallathadka, L. K. (2020). The impact of social responsibility on organizational performance. European Journal of Molecular \& Clinical Medicine, 7(11), 8288-8304.

Perry, P. (2012). Exploring the influence of national cultural context on CSR implementation. Journal of Fashion Marketing and Management: An International Journal, 16(2), 141160.

Pomering, A. (2017). Communicating CSR Through Corporate Image Advertising. In Handbook of Integrated CSR Communication, pp 171-190. Springer International Publishing.

Samuel, K. E., Goury, M. L., Gunasekaran, A., \& Spalanzani, A. (2011). Knowledge management in supply chain: An empirical study from France. The Journal of Strategic Information Systems, 20(3), 283-306.

Sardianou, E., Stauropoulou, A., \& Kostakis, I. (2017). Analyzing Consumers' Awareness towards CSR, Focusing on Environmental Management. Environmental Management and Sustainable Development, 6(2), 51-64.

Tahir, N. S., Ahmad, K., \& Abd Manaf, N. H. (2015). The Managers' Perception on Importance of Religiosity and Corporate Social Responsibility in Malaysia. Journal of Administrative Science, 12(1), 73-86.

Wetzels, M., Odekerken-Schroder, G., \& Van Oppen, C. (2009). Using PLS Path Modeling for Assessing Hierarchical Construct Models: Guidelines and Empirical Illustration. MIS Quarterly, 33(1), 177-195.

Zou, Z., Liu,Y., Ahmad, N., Sial, M. S., Badulescu, A., Zia-Ud-Din, M., \& Badulescu, D. (2021). What Prompts Small and Medium Enterprises to Implement CSR? A Qualitative Insight from an Emerging Economy. Sustainability, 13(2), 952.

https://doi.org/10.3390/su13020952 